\title{
The Relationship between the Emotional Intelligence of Iranian EFL Learners and Their Performance on the Listening Section of IELTS
}

\author{
Ali Akbar Khomeijani Farahani \\ University of Tehran, Iran \\ Hassti Gholam-Shahbazi \\ English Language Department, Islamic Azad University, South Tehran Branch, Tehran, Iran
}

\begin{abstract}
This study was an attempt to explore the role of emotional intelligence on the whole and its components particularly problem solving in EFL learners' listening comprehension performance in the IELTS tests. For this purpose, a total of 39 advanced learners homogenized according to Oxford Placement Test took part in this study. Participants completed the IELTS listening tests and were asked to fill out the Bar-On emotional intelligence questionnaire. The obtained quantitative data were analyzed using Pearson correlation coefficients. Results indicated a non-significant correlation between the whole EI scores and listening performance of learners. There were, however, a significant relationship between problem solving and EI. The social responsibility component of EI was also found to have a significant relationship with listening. The findings are discussed with regard to the role of the IELTS test as a standardized test and the high level of learners. Implications and suggestions for further research are presented.
\end{abstract}

Index Terms — emotional intelligence, IELTS, listening comprehension, problem solving

\section{INTRODUCTION}

Listening refers to the complex and invisible mental activities that lead to the understanding of the spoken language. It is not only a skill but also a means of learning a second or foreign language. In contrast to past when listening was considered not as an active but as a passive skill, today listening is assuming more and more significance in foreign or second language learning.

Listening has its unique specificities which are essential to learn so that one can better understand the nature of listening. Lynch and Mendelsohn (2002) referred to the following as the unique features of listening:

1. Its usually ephemeral, one-shot nature

2. The presence of a rich prosody (stress, intonation, rhythm, loudness and more), which is absent from the written language.

3. The presence of characteristics of natural fast speech, such as assimilation, making it markedly different from written language.

4. The frequent need to process and respond almost immediately.

The effective listeners know how to use all these factors during the listening process so that the message gets across. Definitely, there are different techniques that listeners use to understand the incoming information. The most prominent ones are the bottom-up and top-down processes. The bottom up processing, according to Nunan (2001), assumes that "listening is a process of decoding the sounds that one hears in a linear fashion, from the smallest meaningful units (or phonemes) to complete texts" (p. 200). According to Anderson and Lynch (cited in Nunan, 2001), the bottom-up processing assumes the listener as a passive tape-recorder because it assumes that the listener in this view functions in the same way as a tape-recorder, taking in and storing messages in much the same way as the tape-recorder.

The alternative top-down process suggests that the listeners begin with the background knowledge, knowledge of the topic, the speakers and their shared knowledge, and the knowledge of context and then start constructing the meaning of the sentences. Listening, when viewed from this perspective, is very close to the concept of schema theory. According to Nunan (2001), schema theory "is based on the notion that past experiences lead to the creation of mental frameworks that help us make sense of new experiences" (p. 201). Nunan (2001) argued that listening is an interactive process which includes both bottom-up and top-down processes. In other words, these two critical processes interact to build the meaning from the incoming information.

The listening process can be affected by several variables both internal and external to the learners. One individual variable known to potentially affect listening is emotional intelligence (EI). EI plays a significantly important role in listening comprehension due to its core skills: 1) emotional awareness 2) ability to manage emotions 3) problem solving. All these elements are presumed to be crucial to the development of listening. In addition to this, EI is an interpersonal skill and innate potential on achievements. According to Jahandar, Khodabandehlou, Seyedi, and Mousavi Dolatabadi 
(2012), emotional intelligence can play a more significant role in learning receptive skills such as listening comprehension that can be enhanced and developed by environment and experience that it is assumed to be one of the major variables in promoting EFL learners. With active listening (the process of fully attending to all parts of a communication) and a high EI, one can able to problem solve, offer help to increase trust, and address people concerns. Moreover, problem-solving is a basic and major issue in people's life. Every human being meets problems to be solved in any way. The whole human capacity including energy, motivation, emotions, experiences, cognitive abilities is wasted in solving problems (Yalin \& Sozen, 2015). However, Iranian EFL learners experience considerable stress when taking IELTS listening test, thus by knowing the relationship between them teachers can better prepare their students for the listening section of IELTS.

\section{A. Emotional Intelligence and the Listening Skill}

As a receptive skill, listening has gained much significance in recent years. Learners need to listen and successfully interpret the speakers' speech so that the communication occurs. In this process, the importance of listener's emotions and his/her ability to manage the stress, anxiety, to overcome the negative attitudes, and to encourage interest in the task are pretty obvious. Therefore, as with the other skills, EQ plays an important role in the success of ESL/EFL learners. However, as the concept of emotional intelligence is a comparatively a novel and burgeoning issue with respect to pedagogical endeavors, research dealing with the numerous implications of this construct for instructional realms still appear to be infrequent.

Badakhshan (2008) examined the relationship between the total EQ and its subcomponents with the listening ability of the Iranian EFL learners. The study was also an attempt to compare male and female learners regarding the listening comprehension. To this end, 177 intermediate university students were selected from 265 students. Participants were administered the Bar-On EQ questionnaire and a listening test including 40 questions. The results were analyzed using a Pearson correlation. Findings showed that there were statistically significant relationship between emotional intelligence and listening comprehension ability of the students. Specifically all of the components of emotional intelligence except for the empathy component had a strong relationship with the listening ability of the students. Considering gender, males were much more emotionally intelligent than their female peers with regard to the emotional intelligence.

The studies conducted by Pishghadam (2009) are the pioneer studies in this area. As referred to above, the studies of Pishghadam covered all the skills, one of which was the listening skill. The results of one of the studies (2009) showed that there were no significant differences among the three groups in listening ability, meaning that neither emotional intelligence nor verbal intelligence had any effect on this skill. In the other study carried out by Pishghadam (2009), listening was affected by some subcategories of emotional intelligence such as interpersonal, stress management, and total EQ.

In another study, Aghasafari's (2006) revealed a significant relationship between overall emotional intelligence measure and listening comprehension strategies. The study by Hasanzadeh and Shahmohamadi (2011) looked into the interrelatedness of emotional intelligence and listening strategies of 100 university learners majoring in different fields. The administration of Bar-On's EQ-i and Strategies Inventory pinpointed a significant relationship between the learners' emotional intelligence and their listening strategies. Nevertheless, regarding the relationship between the learners' disciplines and their emotional intelligence and listening strategies no significant results were reported in this study.

The results of these studies refer to the role of EI in facilitating the listening comprehension of learners. However, it is still not clearly known if the problem-solving component eases or hampers learners' attempts in understanding the speech they listen to. The present study was therefore an attempt to investigate the relationship between the problem solving component of EI and the listening performance of EFL learners in IELTS test.

\section{B. Problem Solving}

One of the effective ways of teaching listening to students that has caught considerable attention is the use of problem-solving skills. Previously, Larsen-Freeman (1986) suggested that teaching is an exercise in problem solving tasks. According to this model teaching involves the ongoing solution of series of problems.

There are advantages and disadvantages associated with the use of problem-solving activities in the classroom. For instance, problem solving activities facilitate transfer, retention and increase motivation. Problem solution is achieved when something is also learned. Problem solving is an art which is involved in creating the context in which learning occurs.

According to Ausubel (1963) problem solving as a method of learning requires the learner to discover the higher order principles without specific verbal help. Problem solving or discovery learning involves the combining of the previously learned principles into the new ones that solves the problem and generalizes to an entire class of stimulus situations embodying other problems of the same type. The most important and most obvious characteristic of a discovery approach to teaching is that, it requires for less teacher involvement and direction than most methods (Lefrancois, 2011). This issue has a specific significance with regard to the learning of young learners. This approach encourages an inductive method through which young learners can discover the language and learn it. This is in line with the young learners' subconscious and inductive learning abilities and seems to offer a major advantage in teaching 
for young learners. As Corno and Show (1986, as cited in Le Francios, 1991) point out, teachers can offer a continuum of guidance by adapting their teaching to different students and different purposes.

Problem solving is a skill that induces learning through invoking intellectual guess. Learning is the development of the continuous process of cognition. In education, the main emphasis needs to be given to the fact that learners should be asked to think, in other words; they should be taught to solve problems (Kundu \& Tuttoo, 1988). In problem solving, there are five phases of reflective thought, i.e., to think deeply. According to Kundu and Tuttoo (1988), reflective thought may be analyzed in five phases. At two extremes there are pre-reflective or beginning situation in which there is a state of confusion and post reflective situation that is a feeling of mastery over the doubts. There are suggestions among these states of thought such as possible solutions, and intellectualization of the difficulty of a problem to be solved, the use of one suggestion after another as a main idea, reasoning in the sense of developing the assumptions, and testing the hypothesis by overt task.

Kundu and Tutto (1988) stated that learners should get familiar with these five steps in complete thought. Step one describes for the learners the terminal performance, which leads to the solution of problem. Step two deals with analyzing the problem to find out what prerequisite concepts are for its solution and to assess the learners' behavior for the concepts they will need to solve the problem. Step three describes the guidance the teacher must provide to give relevant principles, and step four requires that teachers provide guidance to problem. Step five requires teachers assess the performance of the learners to see whether they can transfer their learning to new and similar problems. These five steps are overlapping and it is not necessary to be followed one after another.

Therefore, problem-based learning purposefully combines cognitive and metacognitive teaching and learning. It is an approach that has been around since the late 1960s (Neufeld \& Barrows, 1974) and engages EFL learners in learning how to learn language and content. When first language learners face problems, they can skillfully cope with them, but second language speakers devote much endeavor to overcome this challenge to express their intended meaning. Understanding second language problem management is essential; nevertheless, in spite of the prominence of problemsolving behavior in learner's comprehension, current language teaching sources do not offer outline tasks for learners as comprehensive frameworks of problem. Problem solving learning can place language learning in the authentic contexts. By posing language learners, problems similar to those faced in real life, teachers can bridge the gap between language use in authentic environments and classroom environment. Furthermore, they demand learners to explore resources other than the teacher, including reference materials and community members, and drawing on knowledge from various subject areas such as mathematics, geography, and science (Duffy \& Savery, 1994).

\section{MEthodology}

The present study intended to investigate the effect of emotional intelligence particularly the problem-solving component on the listening comprehension of learners at the IELTS test. The following research questions were addressed:

1. Is there any significant relationship between Iranian EFL learners' emotional intelligence and their performance on listening section of IELTS?

2. Is there any significant relationship between EI components including problem solving and Iranian EFL learners' performance on listening section of IELTS?

\section{A. Participants}

An initial number of 50 students were selected as the sample of this study, but this number was later declined to 39 according to the proficiency test results. The participants consisted of 18 female and 21 male students ranging from 1542. The participants were non-native speakers of English who were living in Tehran, Iran at the time of the study. Participants were institute learners in Pardisan institution.

\section{B. Instrumentation}

The following instruments were employed for the present study.

1. Oxford Placement Test

For the purpose of estimating students' proficiency levels and determining their homogeneity, a proficiency test, Oxford placement test, was administered. The test consisted of three sections: 40 vocabulary, 40 grammar, and 20 reading questions. Test takers were asked to choose the correct answer from 4 choices. It took about 50 minutes to administer the test.

\section{Listening Section of an IELTS}

The second instrument of this study was the IELTS General listening. It was chosen from the latest published Cambridge practice tests for IELTS book 9. It contained 4 sections with a total number of 40 items to answer. The first section was a conversation between two speakers and the second section was a monologue. The final two sections were concerned with situations related to educational or training contexts. The third section was a conversation between up to four people and the forth section was a monologue. A variety of question types were used including: multiple choice, completion, matching and labeling. In scoring the exam papers each item had one point. Thus, each participant's listening score was scored out of 40. Candidates heard the recording once and answered the questions as they listened. 
The task took 30 minutes plus 10 minutes for participants to transfer their answers to the answer sheet (Khodadady \& Zeynali, 2012).

3. The Bar-On Emotional Intelligence Questionnaire

The bar-on model was used to assess the participants' emotional intelligence level. The Bar-On Emotional Quotient inventory (EQ-i) is a self-report scale. The inventory takes 10-15 minutes to complete, subjects respond on a 5-point Likert scale continuum from "very seldom or not true of me" to "very often or true of me". The original version consists of 133 items containing five expansive areas of skills and 15 factorial components: The first is Intrapersonal emotional intelligence (self-awareness, assertiveness, self-regard, actualization, and independence). The second is Interpersonal emotional intelligence (empathy, interpersonal relationship, and social responsibility). Next is adaptability emotional intelligence (problem solving, reality testing, and flexibility). The fourth is stress management (stress tolerance and impulse control). The last one is general mood (happiness and optimism) (Bar-On, 1997, pp.43-45). In this study to make sure that Iranian students fully comprehended the content, the translated Persian version of this questionnaire was employed. The final version was decreased to 90 items with the same number of components as mentioned above (Zafari \& Biria, 2014).

\section{Procedure}

The data required for the study were collected in three steps. Since the participants had to take the IELTS listening section exam their level of proficiency must be high. Accordingly, the researcher needed to choose those learners that were in an advanced level of language proficiency. Thus, the Oxford Placement Test was the first to be administered for choosing the advanced learners. After scoring the papers the number of participants was reduced to 39, since their language level did not correspond to that of the other participants. In the next step, the homogenized participants were ready to take the IELTs listening exam. The IELTs test was taken from Cambridge book. The exam took about 40 minutes. It contained four sections. Participants had to answer different types of questions within the limited time. It is noteworthy that the listening texts were played once and they were allowed to take notes. Then, all the papers were scored out of 40 .

Finally, a Persian written emotional intelligence questionnaire was given to the participants containing 90 items. The participants were asked to read the questionnaire carefully and choose their answers among the five options provided in the sheet ( 1 the least appropriate item for describing the person and 5 the most appropriate item for describing the person). Next, the questionnaire was analyzed and the total score for each category was written in front of it. Then the scores of each question were added up together.

The data that were gathered from EI questionnaire and listening section of IELTS were analyzed for each person. The score of each subject was compared with his/her EI score.

\section{Data Analysis}

All the analysis was carried out by means of the Statistical Package for Social Sciences (SPSS, version 21). First of all, there was a brief analysis about the participants followed by a table and histogram. Next, one-sample KolmogorovSmirnov tests were used to check the normality for EI scores, problem solving and listening scores, the same test was used to check the normality of the components of EI questionnaire. Next, in order to see whether there were any significant relationship between the EQ and problem solving scores of Iranian EFL learners and their performance on IELTS listening section the Pearson Correlation Coefficients were administered.

\section{RESULTS}

In order to examine the relationship between EQ, problem solving of Iranian EFL learners and their performance on IELTS listening section, a Pearson correlation coefficient was run. The results are shown in Table 1 and Table 2.

TABLE I.

PEARSON CORRELATION FOR EQ SCORES AND IELTS LISTENING

\begin{tabular}{lccc}
\hline & & EQ & \multicolumn{2}{c}{ IELTS listening } \\
\hline EQ of Iranian EFL learners & Pearson Correlation & 1 & -.047 \\
& Sig (2-tailed) & & .388 \\
& $\mathrm{~N}$ & 39 & 39 \\
\hline
\end{tabular}

Table 1 indicates a non-significant relationship between emotional intelligence of Iranian EFL learners and their performance on IELTS listening section, $p=.38, r=-.04$.

TABLE II.

PEARSON CORRELATION FOR PROBLEM SOLVING AND IELTS LISTENING

\begin{tabular}{llcc}
\hline & & problem solving & IELTS listening \\
\hline PS of Iranian EFL learners & Pearson Correlation & 1 & .312 \\
& Sig (2-tailed) & 39 & .027 \\
& $\mathrm{~N}$ & 39 & 39 \\
\hline
\end{tabular}


According to Table 2, there is a significant, moderate and positive correlation between the problem solving of Iranian EFL learners and their performance on IELTS listening section, $\mathrm{p}=.02, \mathrm{r}=.31$. In other words, if the problem solving skills of the learners increases a unit, their performance on the IELTS listening section would increase as well and vice versa.

Table 3 demonstrates the relationship between IELTS listening scores and each subcategory of EI questionnaire.

TABLE III.

PEARSON CORRELATION BETWEEN IELTS LISTENING AND COMPONENTS OF EI

\begin{tabular}{|c|c|c|}
\hline & & IELTS listening \\
\hline \multirow[t]{3}{*}{ Happiness } & Pearson Correlation & -.209 \\
\hline & Sig (2-tailed) & .201 \\
\hline & $\mathrm{N}$ & 39 \\
\hline \multirow[t]{3}{*}{ Independence } & Pearson Correlation & -.145 \\
\hline & Sig (2-tailed) & .377 \\
\hline & $\mathrm{N}$ & 39 \\
\hline \multirow[t]{3}{*}{ Stress Tolerance } & Pearson Correlation & -.076 \\
\hline & Sig (2-tailed) & .645 \\
\hline & $\mathrm{N}$ & 39 \\
\hline \multirow[t]{3}{*}{ Self-Actualization } & Pearson Correlation & -.094 \\
\hline & Sig (2-tailed0 & .569 \\
\hline & $\mathrm{N}$ & 39 \\
\hline \multirow[t]{3}{*}{ Emotional Self Awareness } & Pearson Correlation & .036 \\
\hline & Sig (2-tailed) & .827 \\
\hline & $\mathrm{N}$ & 39 \\
\hline \multirow[t]{3}{*}{ Reality Testing } & Pearson Correlation & -.186 \\
\hline & Sig (2-tailed) & .257 \\
\hline & $\mathrm{N}$ & 39 \\
\hline \multirow[t]{3}{*}{ Interpersonal Relationship } & Pearson Correlation & -.046 \\
\hline & Sig 92-tailed) & .783 \\
\hline & $\mathrm{N}$ & 39 \\
\hline \multirow[t]{3}{*}{ Optimism } & Pearson Correlation & .258 \\
\hline & Sig (2-tailed) & .113 \\
\hline & $\mathrm{N}$ & 39 \\
\hline \multirow[t]{3}{*}{ Self-Reliance } & Pearson Correlation & -.183 \\
\hline & Sig (2-tailed0 & .266 \\
\hline & $\mathrm{N}$ & 39 \\
\hline \multirow[t]{3}{*}{ Impulse Control } & Pearson Correlation & .033 \\
\hline & Sig (2-tailed) & .842 \\
\hline & $\mathrm{N}$ & 39 \\
\hline \multirow[t]{3}{*}{ Flexibility } & Pearson Correlation & -.182 \\
\hline & Sig (2-tailed) & .268 \\
\hline & $\mathrm{N}$ & 39 \\
\hline \multirow[t]{3}{*}{ Social Responsibility } & Pearson Correlation & .341 \\
\hline & Sig (2-tailed) & .034 \\
\hline & $\mathrm{N}$ & 39 \\
\hline \multirow[t]{3}{*}{ Empathy } & Pearson Correlation & .038 \\
\hline & Sig (2-tailed) & .818 \\
\hline & $\mathrm{N}$ & 39 \\
\hline \multirow[t]{3}{*}{ Assertiveness } & Pearson Correlation & -.222 \\
\hline & Sig (2-tailed) & .174 \\
\hline & $\mathrm{N}$ & 39 \\
\hline
\end{tabular}

Table 3 clearly indicates the existence of a significant relationship only between the social responsibility component of EI and the listening performance of learners, $p=03, r=.34$. Other components were found to be non-significantly correlated to listening comprehension.

Discussion

The present study intends to investigate if there was any relationship between Iranian EFL learners' emotional intelligence, problem solving and their performance on listening section of IELTS exam. Findings illuminated a nonsignificant correlation between emotional intelligence and listening section of the IELTS exam. This finding is in contrast with previous theoretical and empirical studies (Valizadeh \& Alavinia 2013; Alavinia \& Mollahossein 2012). Valizadeh and Alavinia (2013) revealed a strong relationship between listening comprehension performance of the learners and their emotional intelligence scores, with the strongest relationship belonging to the self-awareness subscale of EI. In addition, EI was a proper predictor of listening comprehension performance of learners. Alavinia and Mollahossein (2012) also came up with a significant amount of correlation between the use of listening metacognitive strategies and total emotional intelligence score as well as the learners scores on the subscale of emotional intelligence (intrapersonal, interpersonal, adaptability, and general mood). The non-significant finding of the present study might be attributed to the two factors: 1) the advanced level of learners and b) the nature of the listening test. Firstly, since learners in this study were advanced level EFL learners whose purpose was to take part in the IELTS exam and attain a high score on the test, they might not have attended to the emotional dimension of listening; rather, they were more focused on the outcome of the test. Secondly, the nature of IELTS test with different types of questions such as multiple 
choice, short answer and extended listening text might have caused anxiety and lack of concentration among learners to make use of their EI.

Results, however, indicated a significant and positive correlation between the problem solving of Iranian EFL learners and their performance on IELTS listening section. The findings of the study are in line with those of Goh and $\mathrm{Hu}$ (2013). The study sought to explore the relationship between metacognitive awareness and listening performance. The results showed a significant positive relationship between learner's metacognitive awareness scores and listening performance. Analysis of individual factors showed a significant relationship between listening performance and the strategies of directed attention and problem solving. Results are, however, in contrast with what Jahandar, Khodabandehlou, Seyedi and Mousavi (2012) found in examining the effect of each EI component on listening comprehension. The findings revealed that stress tolerance, interpersonal relationship and flexibility had great impact on listening. To put in a nutshell, by improving problem solving as one of the components of EI, there is a possible chance to increase learners' listening scores.

\section{CONCLUSION AND IMPLICATIONS}

The results of the present study provide some implications for EFL teachers, learners and teacher trainers. The purpose of the educational system is to equip learners with strategies to cope with stressful and challenging situations that they might face in the learning process. Emotionally intelligent people are better able to deal effectively with the challenging situations. This skill in overcoming stressful situations can be implemented to listening tasks, as well. Although the findings of this study did not indicate a relationship between EI components (except social responsibility and problem solving) and listening, it is obvious that this was due to some factors such as the test type, the lack of previous education about the significance of EI and the individual characteristic of the individuals. The findings of the present study revealed a significant relationship between the problem solving component of emotional intelligence and listening comprehension. With respect to the fact that EI is developmental (Davies, Stankov \& Roberts, 1998; Mayer, Salovey \& Caruso, 2000), language learners need to be trained emotionally. Concerning the mediatory role of emotions between sensory input and cognition, having a high level of emotional quotient is expected to facilitate learners' better understanding of input. Teachers are therefore suggested to teach their learners to handle the listening task by employing appropriate problem solving strategies when they are situated in a puzzling context and this is an aspect of training EI in learners. Teachers can also direct learners towards learning more about their feelings and emotions and strengthen their positive emotions. Furthermore, being aware of their own emotions can help learners in establishing goals, monitoring their success in carrying out activities and appraising what they have performed. These are the strategies that learners can use considering their emotional intelligence.

Studies also show that parents' involvement increases the likelihood that students will improve their EI competencies (Weissberg \& O'Brien, 2004). This means that both parents and more importantly teachers as educators of learners need to be familiar with the concept, striving hard first to raise their own emotional competencies and then to try to enhance the emotional intelligence of their learners. Materials developers are also encouraged to include techniques which pay more attention to emotional factors, leading the learners to more self- and other-discovery. Some helpful techniques which can be used to increase emotional intelligence in the classroom include: discussion, listening to light music, watching emotional clips, self-disclosure, designing questionnaires and reading literature and psychological texts (Pishghadam, 2009). If school teachers use these EI strategies, allowing students to learn to know themselves and others, understand how to act and care for others, students will integrate these principles into their everyday lives.

There were a number of limitations in the present study that necessitate the conduction of further studies in this area. Firstly, as stated above, the standardized nature of the IELTS test might have intervened in the outcomes of this study. Further studies are encouraged to examine other listening tests or listening tasks such as listen and do tasks (Ellis, 2003) which are more meaning-based and are expected to better tap into the learners EI development. Secondly, the low sample size of this study needs to be enhanced in future studies by examining a larger sample of learners. In addition, it is suggested that the relationship between EI and other language skills and abilities be examined in further research. Lastly, the use of computer-assisted learning tools can enhance the learner-friendly atmosphere of the classroom (Khezrlou, 2018) and provide an appropriate context for the development of EI awareness and problem solving activities in the classroom.

\section{REFERENCES}

[1] Aghasafari, M. (2006). On the relationship between emotional intelligence and language learning strategies. Unpublished master's thesis, Allameh Tabataba'i University, Iran.

[2] Alavinia, P., \& Mollahossein, H. (2012). On the correlation between Iranian EFL learners' use of metacognitive listening strategies and their Emotional Intelligence. International Education Studies, 5(6), 189-203.

[3] Ausubel, D. (1963). The psychology of meaningful verbal learning. New York: Grune \& Stratton.

[4] Badakhshan, S. (2008). The relationship between Emotional Intelligence and listening comprehension of Iranian intermediate EFL learners. Iranian Journal of Teaching Languages and Literatures, 9(10), 11-28.

[5] Bar-On, R. (1997). Bar-On emotional quotient inventory (EQ-i): Technical manual (R. Samooei, Trans., Iran, Tehran: Navid Hushazma Press). Toronto, Canada: Multi-Health Systems. 
[6] Davies, M., Stankov, L., \& Roberts, R. (1998) Emotional Intelligence: In Search of an Elusive Construct. Journal of Personality and Social Psychology, 75, 989-1015.

[7] Duffy, T. M., \& Savery, J. R. (1994). Problem-based learning: An instructional model and constructivist framework. In Brent G. Wilson (Ed.), Constructivist learning environments: Case studies in instructional design (pp. 183-512). Englewood Cliffs, NJ: Educational Technology Publications.

[8] Ellis, R. (2003). Task based language learning and teaching. Oxford: Oxford University Press.

[9] Goh, C., \& Hu, G. (2013). Exploring the relationship between metacognitive awareness and listening performance with questionnaire data. Language Awareness, 23(3), 11-28.

[10] Hasanzadeh, R., \& Shahmohamadi, F. (2011).Study of emotional intelligence and learning strategies. Procedia Social and Behavioral Sciences, 29, $1824-1829$.

[11] Jahandar,S., Khodabandehlou, M., Seyedi, G., \& Mousavi Dolatabadi, R. (2012). The Impact of Emotional Intelligence on Iranian EFL Learners Listening Proficiency. International Journal of Scientific \& Engineering Research, 3(7).

[12] Jahandar, S., Khodabandehlou, M., Seyedi, G., \& Mousavi Dolatabadi, R. (2012). A gender-based approach to pronunciation accuracy of advanced EFL learners. International Journal of Scientific \& Engineering Research, 3(6), 1-9.

[13] Khodadady, E., \& Zeynali,S. (2012). Field Dependence/Independence Cognitive Style and Performance on the IELTS Listening Comprehension. International Journal of Linguistics.

[14] Khezrlou, S. (2012). The relationship between cognitive and metacognitive strategies, age and level of education. The Reading Matrix, 12(1), 50-61.

[15] Khezrlou, S. (2018). Form-focused instruction in CALL: What do learners think? RELC, 1-17.

[16] Khezrlou, S., Ellis, R., \& Sadeghi, K. (2017). Effects of computer-assisted glosses on EFL learners' vocabulary acquisition and reading comprehension in three learning conditions. System, 65, 104-116. 0033688217738820

[17] Kundu, C.L., \& Tutoo, D. N. (1988). Educational psychology. New Delhi: Sterling Publishers

[18] Larsen-Freeman, D. (1986). Techniques and principles in language teaching. Oxford: Oxford University Press.

[19] Lee, J. H., \& Levine, G. S. (2018). The effects of instructor language choice on second language vocabulary learning and listening comprehension. Language Teaching Research, 1-23. 1362168818770910.

[20] Lefroncois, G. R. (1991). Psychology for teaching. Washington, D.C.: Wordsworth.

[21] Lefroncois, G.R. (2011). Educational Psychology, Bridge Point.

[22] Lynch, T., \& Mendelsohn, D. (2002). Listening. In N. Schmitt (Ed.), An introduction to applied linguistics (pp. 193-210). London: Arnold.

[23] Mayer, J. D., Salovey, P., \& Caruso, D. R. (2000). Models of emotional intelligence. In R. J. Sternberg (Ed.), Handbook of human intelligence (2nd ed., pp. 396-420). New York: Cambridge.

[24] Meysam,Z., Biria, R. (2014). The Relationship between Emotional Intelligence and Language Learning Strategy Use. ProcediaSocial and Behavioral Sciences.

[25] Neufeld, V. R., \& Barrows, H. S. (1974). An approach to medical education. Journal of Medical Education, 49(11), 1040-1050.

[26] Newton, J. M., Ferris, D. R., Goh, C. M., Grabe, W., Stoller, F. L., \& Vandergrift, L. (2018). Teaching English to second language learners in academic contexts: Reading, writing, listening and speaking. New York: Routledge.

[27] Nunan, D. (2001). Second language teaching and learning. Boston: Henile \& Henile Publishers.

[28] Pishghadam, R. (2009). Emotional and verbal intelligences in language learning. Iranian Journal of Language Studies, 3, $43-64$.

[29] Valizadeh, M., \& Alavinia, P. (2013). Listening comprehension performance viewed in the light of emotional intelligence and foreign language listening anxiety. English Language Teaching, 6(12), 11-26.

[30] Weissberg, R.P., \& O'Brien, M.U. (2004). What works in school-based social and emotional learning programs for positive youth development. The Annals of the American Academy of Political and Social Science, 591(1), 86-97.

[31] Yalin, E. \& Sozen, I. (2015). A study of the degrees of emotional intelligence on problem solving skills in the way of Daniel Goleman. Kastamonu University, Unpublished Dissertation Thesis.

Ali Akbar Khomeijani Farahani is an associate professor of English and Linguistics in the English department of the University of Tehran. He has been teaching linguistics and English in this department for more than 21 years. His research interests include discourse analysis and systemic functional linguistics. He has taught extensively in these areas at MA and PhD level.

He received hid PhD in Linguistics from Leeds University UK in 1990. He received his MA in the same field in 1986 from the same University.

Dr. Khomeijani Farahani has already published quite a few articles on different topics related to linguistics and foreign language teaching and a book. Two of the most recent articles and the book are:

Articles

1) Studies on Oral Error Correction: Do they provide Counterevidence against Nativist Arguments? (2017)

2) The Relationship between Temporal Measures of Oral Fluency and Ratings of Fluency: A Case study of Iranian Advanced EFL Learners (2017)

Books:

1) Essential Roots: Prefixes and Suffixes (2012) Jungle publishing house Tehran, Iran

2) An Introduction to Applied Linguistics (2018) Danesh Mana Publishing house Tehran, Iran 


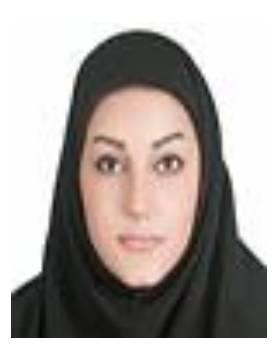

Hassti Gholam-Shahbazi was born in Toronto, Canada in 1994. She holds an M.A in TEFL from Islamic Azad University South Tehran branch (2018) and a B.A in English Literature from Islamic Azad university North Tehran branch (2016).

She has 2 years of experience of working as a English teacher at Pardisan institute at Janbazan Sharghi street in Tehran, Iran. 